\title{
VALIDITY OF STATE RESTRICTIONS ON TESTAMENTARY DISPOSITION TO THE UNITED STATES*
}

FREEDOM in making a will, while an accepted principle of American law, ${ }^{1}$ is seldom considered a constitutionally protected right. ${ }^{2}$ Accordingly state statutes prescribe the persons capable of making a will, ${ }^{3}$ detail the requisite formalities, ${ }^{4}$ and determine what property may be devised. ${ }^{5}$ California and a

leaves me cold. Enforcentent or protection of the rights of ast indizidnal is surcly not adequate if it tums on the antount or increase of the judicial labors in the Fcderal courts. It may be true that ninety-nine out of every hundred petitions of these convicts, who allege that the rights of the Federal Constitution were denied them, are mistaken, and the applications are without merit. On the other hand, it may be that one in a hundred is entitled to the relief. Clearly, no Federal court may say nay, before hearing, to any petitioner who, iis or out of jail asserts his confinement resulted from a denial of a right so treasured as those found in the Federal Constitution." Judge Evans concurring in Potter v. Dowd, 146 F.2d 244, 249 (7th Cir. 1944) (emphasis added). Judge Evans has suggested that if the courts are too busy to hear petitions, a separate court be created for this purpose. Id. at 250.

*Estate of Burnison, 33 Cal.2d 638, 204 P.2d 330, aff'd sub nom. United States y. Burnison, 18 U.S.L. WEEK, 4190 (U.S. March 13, 1950).

1. See, e.g., In re Rahn, 316 1Lo. 492, 502, 291 S.W. 120, 124, cert. deried sub nom. Martin v. Ahrens, 274 U.S. 745 (1927); Thosmson, Wuls $\$ 17$ n.2 (3d ed. 1947).

2. "Nothing in the Federal Constitution forbids the legislature of a state to limit, condition, or even abolish the power of testamentary disposition over property within its jurisdiction." Irving Trust Co. v. Day, 314 U.S. 556, 562 (1942). See 1 PAGE, Wrus $\$ 25$ n.l (3d ed. 1941); The Federalist, No. 33 at 201 (Miodern Library ed. 1937) (Hamilton cites descent as one field into which Congress might not trespass) ; cf. Morton, The Theory of Inhieritance, S Harv. L. KEv. 161, 162 (1S94); IIII, Prmcrpues of Political Econosy bk. II, c. II $\$ 4$ (Ashley ed. 1923). Wisconsin is alone in asserting that freedom of testation is constitutionally protected. See Will of Rice, 150 Wis. 401, 444-7, 136 N.W. 956, 973-4 (1912). Even Wisconsin, however, is willing to grant that testation may be subjected to reasonable legislative regulation. Nunnemscher v. State, 129 Wis. 190, 108 N.W. 627 (1906).

But state power to regulate devolution of property, while broad, certainly has some constitutionally imposed limitations. See Clark v. Allen, 331 U.S. 503 (1947) (treaty' provisions will prevail over any conflicting requirements of state probate law); Buchanan v. Warley, 245 U.S. 60 (1917) (city ordinance preventing alienation of property to Negroes violates the Fourteenth Amendment); see Oyama v. California, 332 U.S. 633, 640 (1948); Magoun v. Illinois Trust and Savings Banl, 170 U.S. 283, 293 (1898). But cf. Peterson v. Iowa, 245 U.S. 170 (1917) ; MLoody v. Hagen, 36 N.D. 471, 162 N.W. 704, aff'd per curian stb nom. Skarderud v. North Dakota Tax Commission, 245 U.S. 633 (1917).

3. E.g., Cax. Civ. Code $\$ 1292$ (18S9), In re Comassi, 107 Cal. 1, 4, 40 Pac. 15, 16 (1895). See Matter of Delano, 176 N.Y. 486, 491, 68 N.E. 871, 872 (1903), aff'd sisb rom. Chanler v. Kelsey, 205 U.S. 466 (1907).

4. E.g., N.Y. DEC Est. LAW $\$ 47$ (1909), Higgins v. Eaton, 183 Fed. 938 (C.C.N.D.N.Y. 1911), rev'd on other groustds, 202 Fed. 75 (2d Cir. 1913); N.C. REv. Laws $\$ 3113$ (1905), Peace v. Edwards, 170 N.C. 64, 86 S.E. 807 (1915) ; Mfrimi. Geri. STAT. c. $47 \$ 5$ (1867), In re Penniman, 20 Minn. 245 (1873).

5. E.g., ORE. CODE $\$ 3066$ (Hill, 1887), Hardenbergh v. Ray, 151 U.S. 112 (1894). 
few other states also stipulate who may receive a bequest or devise. ${ }^{0}$ The California Probate Code allows natural persons, the state, counties, and fourteen types of public corporations and associations to take by will.7 "No other corporation can take under a will, unless expressly authorized by statute." 8 Faced with this statute, the California Supreme Court, in Estate of Burnison, ${ }^{9}$ invalidated a bequest to the United States Government. ${ }^{10}$

Doctrinally the California court was on firm ground. The Probate Code discloses no legislative intent to include the United States in any specific class of eligible legatees. ${ }^{11}$ No other California law mentions the Govern-

6. Cal. Prob. Code $\$ 27$ (Deering, 1949); New York's law, the first prohibiting testamentary disposition to corporations not authorized by statute to take under a will, applies only to devises. N.Y. Dec. Est. Law §12, Downing v. Marshall, 23 N.Y. 366, 386 (1861). States subsequently enacting legislation narrowing classes of eligible legatees extended the restriction to bequests. MoNr. REv. Code tit. 91, $\$ 104$ (Choate \& Wertz, 1947) ; N.D. Rev. Code § 56-0205 (1943); OkLA. Stat. ANn. tit. 84 § 45 (1938); S.D. CODE $\$ 56.0205$ (1939).

7. "A testamentary disposition may be made to the state, to counties, to municipal corporations, to natural persons capable by law of taking the property, to unincorporated religious, benevolent or fraternal societies or associations or lodges or branches thereof, and to corporations formed for religious, scientific, literary, or solely educational or hospital or sanitarium purposes, or primarily for the public preservation of forests or natural scenery, or to maintain public libraries, museums or art gallerics, or for similar public purposes. . . " CAL. Prob. CoDa § 27 (Deering, 1949).

The Section, as first enacted in 1872, CAL. Crv. CoDE $\$ 1275$ (1872), allowed no corporation to take from a California testator unless expressly permitted by statute. The legislature, as expediency dictated, excepted one corporation after another from this requirement of statutory authorization. No serious attempt has been made to rewrite the provision in a more rational fashion. See Estate of Burnison, 33 Cal.2d 638, 641, 204 P.2d 330, 332 (1949); Bodfish, The Destructive Effect of the 1937 Amendment of Section 42 of the Probate Code of Califomia upon the Limitations Regarding Testamentary Disposition to Charities, 26 CALIF. L. REv. 309, 322 (1938).

8. Cal. Prob. Code $\$ 27$ (Deering, 1949).

9. 33 Cal.2d 638, 204 P.2d 330, aff'd sub nom. United States v. Burnison, 18 U.S.L. WeEK 4190 (U.S. March 13, 1950). Estate of Sanborn, 33 Cal.2d 647, 204 P.2d 335, aff'd sub nom. United States v. Gayetty, 18 U.S.L. WeEk 4190 (U.S. March 13, 1950) was decided the same day, and joined on appeal to the United States Supreme Court.

10. The few reported cases which have involved testamentary disposition to the United States agree that the disposition's validity depends on state law. United States v. Fox, 94 U.S. 315 (1876) (United States cannot be a devisee when prohibited by state statute); Dickson v. United States, 125 Mass. 311 (1878) (Government can take when not inhibited by state law); see United States v. Perkins, 163 U.S. 625, 629 (1896); cf. Mississippi Valley Trust Co. v. Ruhland, 222 S.W.2d 750, 752 (Mo. 1949). In England the nation's right to take by will is well established. E.g., Re Smith, [1932] $1 \mathrm{Ch} .153$; Nightingale v. Goulburn, 5 Hare 484, 67 Eng. Rep. 1003 (Ch. 1847), aff'd, 2 Ph. 594, 41 Eng. Rep. 1072 (Ch. 1848).

11. California confines eligible legatees to those specified by the Probate Code. E.g., Estate of Barter, 30 Cal.2d 549, 184 P.2d 305 (1947) (British government ineligible); In re Loring's Estate, 168 P.2d 224 (Cal. D. Ct. App.) rev'd on other grounds, $29 \mathrm{Cal} .2 \mathrm{~d}$ 423,175 P.2d 524 (1946). Two years before the Burnison case, a California court had validated a bequest to the Veterans Administration. The court felt that the legislature 
ment as a proper recipient of a testamentary gift.12 While federal law might supply the necessary statutory authorization, ${ }^{13}$ no congressional statute of general application authorizes the United States to acquire property by will. ${ }^{14}$ Thus a testamentary disposition to the United States is void, unless the California law could be proved unconstitutional. And the Supreme Court of the United States, reviewing the Burnison case on appeal, set this doubt to rest by upholding California's right to bar bequests to the Government. ${ }^{15}$

The Government maintained that the California statute could not stand in the face of the Supremacy Clause. ${ }^{16}$ In the absence of restrictive state legislation, the United States undoubtedly can accept a voluntary bequest as an incident to its sovereignty. ${ }^{17}$ If in addition the Government's inherent

could scarcely have intended excluding the United States from taking under a California testator's will. Estate of Hendrix, 77 Cal. App.2d 647, 652, 176 P.2d 398, 401 (1947). Although a federal statute authorized the Veterans Administration to talie by will, see note 14 infra, the statute was not essential to the decision. The dissenting judge in the Burnison case believed that the Fendrix decision should be followed. 33 Cal.2d 638, 646, 204 P.2d 330, 335 (1949). See also note 12 infra. For an implication that the drafters of the Probate Code failed to anticipate exclusion of the Government from taling by will, see Evans, Comments on the Probate Code of Califormia, 19 CALIr. L. Rev. 602,609 (1931).

12. A corporation, while not mentioned in the Probate Code, may be authorized by another statute to take by will. CAL. ProB. Code $\$ 27$ (Deering, 1949). Thus California business corporations may be devisees. Car. CoRp. Code Avs., \$802 (Deering, 1947). The same privilege is extended domestic non-profit corporations. Id. $\S 9501$. But the Government is nowhere mentioned.

The legislature did, however, exempt property transferred to the United States from the California inheritance tax. CaL. Revenue and TAx COdE $\$ 13841$ (Deering, 1944). While the United States can acquire property on death by contract, Stevens v. United States, 302 U.S. 623 (1938), it seems more than likely that a transfer by will was contemplated in granting the exemption.

13. See Estate of Burnison, 33 Cal.2d 638, 644, 204 P.2d 330, 333 (1949) ; cf. Iglehart v. Iglehart, 204 U.S. 478 (1907) ; In re Hauge's Estate, 92 MIont. 36, 9 P2d 1065 (1932). Compare Matter of Huss, 126 N.Y. 537, 27 N.E. 784 (1891), wiih In re Crum, 98 Misc. 160, 164 N.Y. Supp. 149 (Surr. Ct. 1916).

14. Congress has, however, enacted nearly a score of statutes authorizing specific agencies to accept bequests and devises. E.g., 60 STAr. 537, 38 U.S.C. $\$ 14$ (1946) (Veterans Administration); 58 SrAT. 709 (1944), 42 U.S.C. $\$ 219$ (1946) (Public Health Service). While these statutes have never been challenged their constitutionality would seem certain. Cf. Hunt v. United States, 278 U.S. 96 (1928); Johnson v. MFaryland, 254 U.S. 51 (1920) ; Ohio v. Thomas, 173 U.S. 276 (1899).

A bequest to the United States goes into "Miscellaneous Receipts," while a bequest for a particular agency is entered in a special fund for that agency. Appellant's Statement of Jurisdiction, p. 7 n.4, United States v. Burnison, 18 U.S.L. WEEE 4190 (U.S. Alarch 13, 1950).

15. United States v. Burnison, 18 U.S.L. WeEx 4190 (U.S. M1arch 13, 1950).

16. The Constitution "and the Laws of the United States . . . and all Trenties ... shall be the Supreme Law of the Iand . . . any Thing in the Constitution or Laws of any State to the Contrary notwithstanding," U.S. CoNsT. Art. VI.

17. Dickson v. United States, 125 Miass. 311 (1878); cf. Fay v. United States, 204 Fed. 559 (1st Cir. 1913) (inter vivos transfer) see Russell v. Allen, 107 U.S. 163, 170 
power to take under a will derived from one of the constitutionally enumerated powers, states could not interfere. But the Supreme Court rejected this argument, holding that there is no overriding federal policy capable of limiting state action. ${ }^{18}$

While legislatures can thus apparently forbid bequests to the United States Government, the limitation is irrational and archaic. State laws restricting bequests and devises are adaptations of the English Statute of Wills, ${ }^{19}$ which was enacted primarily to prevent testamentary dispositions to the Church..$^{20}$ Although this reason has long since vanished, the restraint on a testator's power to convey his property remains. ${ }^{21}$

(1882). The United States appears to have "resultant" powers, i.c., those neither expressed in the Constitution, nor implied by any of its provisions, but which result from the sum of all of its powers. E.g., Neilson v. Lagow, 12 How. 98, 107 (U.S. 1851) (to take security for a debt); United States v. Bradley, 10 Pet. 343, 359 (U.S. 1836) (same); United States v. Tingey, 5 Pet. 115, 127 (U.S. 1831) (to enter into contracts); Dugan v. United States 3 Wheat. 172, 181 (U.S. 1818) (to sue in its own name). But cf. Kansas v. Colorado, 206 U.S. 46, 90 (1907) (powers of a national character not delegated by the Constitution "are reserved to the people").

18. United States v. Burnison, 18 U.S.L. WeEK 4190 (March 13, 1950).

This conclusion also disposed of an alternative claim that California, by permitting testamentary gifts to itself while forbidding them to the United States was unlawfully discriminating against the Federal Government. Id. at 4192. Under the Supremacy Clause a state may not refuse to enforce a right based on federal law while enforcing one based on its own law. E.g., Testa v. Katt, 330 U.S. 386 (1947); Republic Pictures Corp. v. Kappler, 151 F.2d 543, 546-7 (8th Cir. 1945). By analogizing the capacity of the United States to take by will to a right based on federal law, the Gavernment contended that California was unlawfully discriminating. But the Supreme Court disposed of this contention under its previous conclusion that the "power" of accepting bequests could not be elevated to the level of a "right" to do so. And the Court further held that the mere fact that the United States is being treated differently from California constitutes no violation of the Fourteenth Amendment. 18 U.S.L. WEEK 4192.

The Supreme Court had previously intimated that mere incidents to sovereignty are not, by virtue of the Supremacy Clause, immune from curtailment by state legislation. See, e.g., Neilson v. Lagow, 12 How. 98, 107 (U.S. 1851); United States v. Tingey, 5 Pet. 115, 127 (U.S. 1831). See also, Penn Dairies v. Milk Control Commission, 318 U.S. 261 (1943) (where Congress has not specifically exempted sales of milk to United States Army from state milk control law, the Constitution itself implies no immunity from state control).

19. 34, 35 HEN. VIII c. 5 (1542-1543) (a devise may be made to any person except "bodies politick and corporate").

20. The first Statute of Wills, 32 HEN. VIII c. 1 (1540), very nearly ended the carlier ban on testation. Henry evidently felt this was too liberal, for in 1542 he introduced the second Statute of Wills. See note 19 supra. Ostensibly designed to explain the carlier enactment, 4 Holdsworti, A History of ENGLish LAw 466 (1st ed. 1924), the second statute was really aimed at ending the priestly practice of high-pressuring dying parishioners to devise their lands to the Church. 2 BL. Connr. $* 375$.

21. Courts have rarely attempted to justify the continued existence of restrictive will statutes. They are occasionally defended on the ground that corporate ownership in perpetuity should be prevented. Downing v. Marshall, 23 N.Y. 366, 386 (1861). This explanation applies only to devises, and even as so applied is not particularly convincing. 
Fortunately, these statutory carry-overs from a feudal society are easily avoided. Testators have no difficulty in bequeathing property to ineligible legatees. Indeed, several drafting devices are available to effectuate the purpose frustrated in the Burnison case. The simplest method is a bequest to the United States in trust for the American people. ${ }^{22}$ Although the Government, if it is prohibited from accepting the bequest, cannot serve as trustee, ${ }^{23}$ the court has power to appoint a competent substitute. California's Supreme Court, in deciding the Burnison case, might well have implied such a trust. ${ }^{24}$ Similarly, a testamentary disposition to a federal official, in trust for governmental purposes, might succeed. ${ }^{25}$ Also, a transfer at death to the Secretary of the Treasury or any other Government official, probably would not be disqualified as a transfer to the United States.95 While the grantor cannot bind the Government officer, he can express in the document

For the typical restrictive statute allows any corporation to take under a will if it is authorized by law to do so, and there are few corporations not so authorized. Sce note 12 supra. Moreover, the explanation makes little sense when applied to the United States which already owns $46,484,391$ acres of California land in perpetuity, some 46 per cent of the total land in the state. Statistical Abstract of the United States 160 (1949).

One judge has advanced the novel theory that restrictions against testamentary benefactions exist to prevent those who will not be charitable during their lives from being charitable after death. Coleman v. Whipple, 191 Miss. 287, 302, 2 So.2d 566, 569 (1941) (dissenting opinion).

22. Cf. Estate of Barter, 30 Cal.2d 549, 184 P.2d 305 (1947) (bequest to British Government for the benefit of refugee children); Gould v. Board of Home Missions, 102 Neb. 526, 167 N.W. 776 (1918). Contra: Levy v. Levy, 33 N.Y. 97, 122 (1865) (alternative holding) (devise to United States for benefit of children of Naval personnel); sce In re Fox, 52 N.Y. 530, 533 (1873), aff'd sib nonn. United States v. Fox; 94 U.S. 315 (1876).

23. Catt v. Catt, 118 App. Div. 742, 103 N.Y. Supp. 740 (1st Dep't 1907); cf. Estate of Barter, $30 \mathrm{Cal} .2 \mathrm{~d} 549,184$ P.2d 305 (1947). Where no restrictive state statute intervenes, however, there is no objection to the Government's serving as trustee. Yale College's Appeal, 67 Conn. 237, 34 Atl. 1036 (1S96) ; Dickson v. United States, 125 MFass. 311 (1878).

24. Cf. Doughton v. Vandever, 5 Del. Ch. 51, 77 (1S75); Yard's Appeal, 64 Pa. 95, 100 (1870); Zolldian, Asjerican LaW of Charties $\$ 473$ (1924).

25. This device might prove more satisfactory than a bequest to the Government itself in trust. See notes 23 and 24 supra. There would, at least, be no doubt that the trustee could serve. Estate of Robinson, 63 Cal. 620 (1883) (bequest to the Miayor of San Francisco for the destitute of that city upheld where outright bequest to the city would have failed). See the discussion of the Robinson case in In re Loring's Estate, 16S P.2d 224, 231 (Cal. D. Ct. App.), rev'd on other grounds, 29 Cal.2d 423, 175 P.2d 524 (1946). Cf. Christian Church v. Church of Christ, 219 III. 503, 513, 76 N.E. 703, 705 (1905) (to trustees of "Christian Church") ; Tucker v. Seaman's Aid Society, 48 Mass. (7 Mret.) 188, 200 (1843). For a variation of this device, see Rine v. Wagner, 135 Iowa 626, 113 N.W. 471 (1907) (to "Right Reverend James O'Connor, bishop of Omaha . . . [or] his successor" for charitable purposes).

26. Cf. Flood v. Ryan, 220 Pa. 450, 69 Atl. 908 (1908) (to "Most Rev. J. J. Ryan archbishop of Philadelphia"); Iir re Hodnett, 154 Pa. 485, 26 Atl. 623 (1893) (to "the pastor of the St. John's R.C. Church"). A bequest to an individual in trust for a charity, 
his wishes that the property be devoted to Government use. ${ }^{27}$ And, finally, a grantor could establish an inter vivos trust, reserving a life estate and a power to revoke, and naming the United States as beneficiary. ${ }^{28}$ Under this device the grantor retains use of the property for life and the eligible legatee statute is avoided on two counts: the transfer is inter vivos and it is to a private trustee.

It is unrealistic for states to invalidate direct bequests to the United States if drafting devices can accomplish the same result indirectly. States with restrictive statutes should enlarge the class of eligible legatees to include the United States. If state laws are not broadened, however, a federal statute authorizing the Government to take by will should be enacted. This would permit bequests to the Government in those states which, like California, require express authorization "by statute." A law of this type would not raise problems under the Tenth Amendment so long as it recognized the states' apparently primary power to determine testamentary succession. ${ }^{29}$ Although this legislation would solve the problem of bequests to the

however, would fail wherever the charity could not take directly. In rc Houk's Estate, 186 Cal. 643, 200 Pac. 417 (1921).

This avoidance device has the further advantage of simultaneously escaping additional statutes which limit the portion of an estate a testator may leave for charitable uses. Cf. CAL. Prob. Code $\$ \S 40-43$ (Deering, 1949) ; Mont. Rev. Code tit. 91, $\$ 142$ (Choate \& Wertz, 1947) ; N.Y. Dec. Est. LaW \$17; Thompson, Wuls \$24 (3d ed. 1947). If property is left to a government official, it cannot be said to be devoted to charitable uses.

27. Cf., e.g., Estill v. Ballew, 26 S.W.2d 778 (Mo. 1930) ("I request that she. . . ."); Matter of Keleman, 126 N.Y. 73, 26 N.E. 968 (1891). The principal weakness of precatory language is that the legatee and his successors in interest remain wholly unbound. Zollasan, op. cit. supra note 24, \$512 ("Human Nature is Human Nature, and the risk of an abuse of the confidence reposed is always present").

Should the legatee be notified of the testator's wish before his death, courts may infer the creation of a secret trust, though the legatee has never expressed assent. In such a case, the charitable beneficiary would be limited to the statutory share of the estate. Sic Smith v. Havens Relief Fund Society, 44 Misc. 594, 614, 90 N.Y. Supp. 168, 179 (Sup. Ct. 1904) ; Gore v. Clarke, 37 S.C. 537, 550, 16 S.E. 614, 619 (1892). Contra: O'Donnell v. Murphy, 17 Cal. App. 625, 120 Pac. 1076 (1911), where the legatee advised the testatrix that her bequest would fail if left in trust, whereupon she revised her will leaving the bequest to the legatee absolutely. Cf. In re Bickley's Estate, $270 \mathrm{~Pa} .101,113 \mathrm{Atl} .68$ (1921) (bequest to charity or in the alternative to head of charity).

28. Cf., e.g., President of Bowdoin College v. Merritt, 75 Fed. 480 (C.C.N.D. Cal. 1896), appeal dismissed, 167 U.S. 745 (1897); Cleveland Trust Co. v. White, 134 Ohio St. 1, 15 N.E.2d 627 (1938). See Leaphart, The Use, A Factor in the Law Today, 79 U. of PA. L. REV. 253, 261 (1931). This is the principal and most effective device for escaping testamentary restraints. It, too, will avoid any state law allowing only a small percentage of an estate to be bequeathed or devised for charitable uses. See note 26 supra. A settlor who retains too much control, however, may be found to have made no transfer at all. - In re Tunnell, $325 \mathrm{~Pa}$. 554, 190 At1. 906 (1937) (settlor constituted himself trustee, retaining right to income and power to revoke or modify the trust).

29. E.g., Steward Machine Co. v. Davis, 301 U.S. 548, 586 (1936); Duke Power Co. v. Greenwood County, 91 F.2d 665, 673 (4th Cir. 1937), aff'd, 302 U.S. 485 (1938).

On the other hand, it is not certain whether a law categorically asserting the unre- 
United States, it would fail to eliminate the anachronistic local prohibitions which prevent disposition to other disfavored legatees. ${ }^{80}$ Among the most frequent sufferers under these prohibitions are municipal, state and foreign governments. While these restrictions seem unjustified in any event, they are especially objectionable when invoked against domestic governments. There is every reason to honor the claims of financially hard-pressed municipalities to bequests. And it is anomolous to discourage concentration of

stricted right of the United States to take by will would survive constitutional objections. Prior to the Burnison case, the virtual demise of the Tenth Amendment seemed to indicate that no very strenuous protest against the statute could be formulated. Cf. United States v. Darby, 312 U.S. 100, 124 (1941). See Feller, The Tenth Anendnent Retires, 27 A.B.A.J. 223 (1941). And the Burnison case provided no clear holding on this issue, since no federal statute was involved. The Court, however, intimated that the power to determine who may take by will is one of the powers reserved to the states by the Tenth Amendment. See United States v. Burnison, 18 U.S.L. WEek 4190, 4191 (U.S. Alarch 13, 1950). A future holding to this effect would invalidate federal legislation creating in the United States the unrestricted power to take by will.

Certainly an argument defending an absolute federal right to inherit would be difficult to frame. The Darby case, supra, involved a specific section of the Constitution, the Commerce Clause, while a statute reducing local control over inheritance would have to be based on a more nebulous power. The ability of the United States to take under a will may result from the sum of all powers. See note 17 supro. But it is apparently not immune from state legislation. Stevens v. United States, 89 F.2d 151, 154 (1937), rev'd on other gromds, 302 U.S. 623 (1938); see Neilson v. Lagow, 12 How. 98, 107 (U.S. 1851) ; United States v. Tingey, 5 Pet. 115, 127 (U.S. 1831).

The Federal Government's power to take by will has been termed inherent. Diclsson v. United States, 125 Mass. 311, 315 (1878). But it is frequently insisted that the United States does not have such powers. See Williams, Inherent Soucreign Pozters of the Federal Government, 6 UnIversity of South Carolna, Yeurfoor of tre Selder SoctETY 1 (1942). In fact, the strongest denial of inherent power, Kansas v. Colorado, 206 U.S. 46 (1906), has not yet been directly attacked. See Scorr, Junicun Sertumaresirs of Controverstes Between States of the Aarertcan Unton 431-53 (1919); 1 WirIOUGHBY, CONSTitutional LAW of tHe UNITEd States $\$ 58$ (2d ed. 1929). Although Willoughby attempts to differentiate between "resultant" and "inherent" powers, id. $\S 54$, the distinction seems ephemeral. Cf. Feller, The Tenth Amendment Relircs, 27 A.B.A.J. 223, 225 (1941) ; 2 Story, Comarentaries on the Constrtution $\$ \$ 1256,1279$ (5th ed., Bigelow, 1891).

If, despite these constitutional difficulties, the Federal Government should adopt a law avowing an absolute right to accept voluntary legacies, several state statutes might prove useful models. See, e.g., Minns. Stat. Ann. \$§7.09-7.12 (1946); Mo. Rev. STat. ANx. $\$ 643$ (Supp. 1949).

30. See note 6 supra. The statutes are summarized in Bordwell, The Statufe Law of Wills, 14 IowA L. Rev. 1, 198 (1928). California, Mrontana and New York have enioreed their enactments rigorously. See, e.g., In re Loring's Estate, 168 P.2d 224 (Cal. D. Ct. App.), rev'd on other grounds, 29 Cal.2d 423, 175 P.2d 524 (1946) (bequest to Iowa town); In re Beck's Estate, 44 Mont. 561, $121 \mathrm{Pac} .784$ (1912) (bequest to State of Montanz); In re Fox, 52 N.Y. 530 (1873), aff'd sib nom. United States v. Fox, 94 U.S. 315 (1876) (devise to United States). Ollahoma has been more liberal. Phillips v. Chambers, 174 Okla. 407, 51 P.2d 303 (1935) (county not a corporation within meaning of statute prohibiting corporations from taking under a will). 